\title{
UJI EFEK EKSTRAK GEDI MERAH (Abelmoschus manihot L. Medik) TERHADAP KADAR GULA DARAH TIKUS PUTIH JANTAN GALUR WISTAR (Rattus novergicus) YANG DIINDUKSI ALOKSAN
}

\author{
${ }^{1}$ Friska Adeline \\ ${ }^{2}$ Jane Wuisan \\ ${ }^{3}$ Henoch Awaloei
}

\author{
${ }^{1}$ Kandidat Skripsi Fakultas Kedokteran Universitas Sam Ratulangi Manado \\ ${ }^{2}$ Bagian Farmakologi dan Terapi Fakultas Kedokteran Universitas Sam Ratulangi Manado \\ Email: fadeline11_008@yahoo.com
}

\begin{abstract}
Epidemiological study in Manado indicated that the prevalence of Diabetes Melitus (DM) was 6.1\%. It is necessary to do scientific assessment of the various species of plants which are thought containing medicinal substances (phytopharmaca). Based on the information from the people living in the subdistrict Pineleng Minahasa red gedi leaves (Abelmoschus manihot L.Medik ) can be used as herbal treatment for lowering blood sugar level. This study aimed to evaluate the effect of red gedi leaves extract in lowering blood sugar level on white male rat induced by aloksan. This study used 15 white male rats of Wistar strain with diabetic induced by $200 \mathrm{mg} / \mathrm{kg}$ BW aloksan intraperitoneal. The rats were randomly divided into 5 groups; each group were given aquadest $2,5 \mathrm{ml} / 200 \mathrm{~g} \mathrm{BW}$, insulin Novomix 0,9 U/Kg BW, red gedi leaf extract $1.25 \mathrm{mg} / 200 \mathrm{~g} \mathrm{BW}, 2.5 \mathrm{mg} / 200 \mathrm{~g} \mathrm{BW}$, and $3.75 \mathrm{mg} / 200 \mathrm{~g} \mathrm{BW}$, once daily for 24 hours. Blood sugar levels were measured at $6^{\text {th }}, 12^{\text {th }}$, $18^{\text {th }}$, and $24^{\text {th }}$ hours after treatment by using glucometer. The result showed that red gedi leaf extract can lower blood level in diabetic white male rat induced by aloksan.
\end{abstract}

Keywords: red gedi leaf extract, blood glucose, aloksan, diabetic

\begin{abstract}
Abstrak: Pada penelitian epidemiologis di kota Manado didapatkan prevalensi penderita DM 6,1 \%. Untuk itu perlu dilakukan pengkajian ilmiah terhadap berbagai spesies tumbuhan yang diduga mengandung zat berkhasiat obat (fitofarmaka). Berdasarkan informasi masyarakat di daerah kecamatan Pineleng kabupaten Minahasa daun Gedi Merah (Abelmoschus manihot L.Medik) dapat dimanfaatkan sebagai penanganan herbal untuk menurunkan kadar gula darah. Penelitian ini bertujuan menguji efektivitas ekstrak daun Gedi Merah (Abelmoschus manihot L. Medik) dalam menurunkan kadar gula darah tikus putih jantan galur Wistar (Rattus norvegicus) yang diinduksi aloksan. Tikus galur Wistar sejumlah 15 dinduksi dengan aloksan intraperitoneal $200 \mathrm{mg} / \mathrm{kg}$ BB dan dibagi secara acak dalam 5 kelompok penelitian yaitu kelompok perlakuan dengan aquadest 2,5 ml/200 g BB, insulin Novomix 0,9 U / Kg BB, ekstrak daun gedi merah 1,25 mg/ 200 g BB, 2,5 mg/ 200 g BB dan 3,75 mg/ 200 g BB. Perlakuan diberikan satu kali sehari selama 6 hari. Pengukuran kadar glukosa darah dilakukan pada hari ke 2, 4 dan 6 setelah perlakuan menggunakan glukometer. Hasil penelitian menunjukkan bahwa ekstrak daun gedi merah dapat menurunkan kadar glukosa darah tikus putih jantan diabetes yang diinduksi dengan aloksan.

Kata kunci: ekstrak daun gedi merah, glukosa darah, aloksan, diabetes
\end{abstract}

Dengan meningkatnya usia, status sosial, serta ekonomi masyarakat Indonesia, maka dapat terjadi peningkatan penyakit metabolisme., salah satunya ialah Diabetes Melitus (DM). Kurang berolahraga dan makan berlebihan menjadi pemicu 
meningkatnya prevalensi DM. ${ }^{1}$ Menurut Konsesus Perkumpulan Endokrinologi Indonesia (PERKENI), pada penelitian epidemiologis di kota Manado didapatkan prevalensi penderita DM 6,1\%. ${ }^{2}$

Berdasarkan informasi masyarakat di daerah kecamatan Pineleng, kabupaten Minahasa bahwa daun Gedi Merah (Abelmoschus manihot L.Medik) dapat dimanfaatkan sebagai penanganan herbal yang dapat menyembuhkan beberapa penyakit, seperti diabetes, kolesterol dan hipertensi. ${ }^{3}$ Daun gedi mengandung banyak senyawa flavonoid yang banyak digunakan untuk penanganan DM. ${ }^{4}$

Penelitian ini dilakukan untuk menguji efektivitas penurun kadar gula darah pada Tikus Putih Jantan Galur Wistar (Rattus norvegicus) setelah pemberian ekstrak daun Gedi Merah (Abelmoschus manihot L. Medik).

\section{METODE PENELITIAN}

Bentuk penelitian ini ialah eksperimental laboratorium. Subyek penelitian ialah tikus putih galur wistar jantan (Rattus norvegicus), umur 3-4 bulan, dan berat badan 150-250 g.

Bahan yang digunakan dalam penelitian ini ialah daun gedi merah (Abelmoschus manihot (L.) Medik), Etanol $96 \%$, aquadest, insulin Novomix dan aqua pro injeksi. Alat yang digunakan dalam penelitian ini ialah wadah toples, batang pengaduk, gelas ukur, sonde oral tikus, dan glukometer Nesco Multicheck.

\section{Penentuan Dosis Insulin}

Dosis insulin untuk manusia dikonversi ke dosis tikus menjadi 0,9 iu/ 200 g BB yang dibuat dari sediaan novomix. Volume maksimal pemberian perlakuan pada tikus putih secara subkutan adalah $0,5 \mathrm{ml}$.

\section{Pembuatan Ekstrak daun Gedi Merah Pengolahan sampel}

Daun Gedi Merah dicuci dengan air mengalir, diangin-anginkan ditempat yang terhindar dari sinar matahari langsung sampai kering, kemudian diserbukkan.

\section{Ekstraksi daun Gedi Merah}

1. Pembuatan $1000 \mathrm{~mL}$ (Farmakope Indonesia Edisi III). Diambil $100 \mathrm{~g}$ simplisia ke dalam sebuah bejana, dituangi dengan $750 \mathrm{~mL}$ cairan penyari yaitu etanol 96\%, tutup biarkan selama 5 hari terlindung dari cahaya sambil sering diaduk, saring menggunakan kain flanel, peras, tambahkan cairan penyari secukupnya $250 \mathrm{ml}$ lalu disaring kembali, hingga diperoleh 1000 ml. Pindahkan ke dalam bejana tertutup, dibiarkan di tempat sejuk, terlindung dari cahaya selama 2 hari, dienap tuangkan atau disaring.

2. Pembuatan sediaan ekstrak daun Gedi Merah dengan dosis:

I. Untuk dosis 1,25 mg/200 g BB Tikus putih: Ditimbang 12,5 mg ekstrak daun Gedi Merah, ditambahkan aquadest sampai 25 $\mathrm{mL}$.

II. Untuk dosis $2,5 \mathrm{mg} / \mathrm{kg}$ BB Tikus putih: Ditimbang $25 \mathrm{mg}$ ekstrak daun Gedi Merah, ditambahkan aquadest sampai $25 \mathrm{~mL}$.

III.Untuk dosis 3,75 mg/kg BB Tikus putih: Ditimbang 37,5 mg ekstrak daun Gedi Merah, ditambahkan aquadest sampai $25 \mathrm{~mL}$.

\section{Perlakuan Hewan Uji}

Delapan belas ekor tikus putih jantan galur wistar, diadaptasi selama 2 minggu dan dikelompokkan secara acak ke dalam 6 kelompokyang terdiri masing-masing atas 3 ekor.

- Kadar gula darah diukur dari sampel darah tikus putih jantan pada masingmasing kelompok, yang diambil lewat sinus marginalis sebelum induksi $\left(\mathrm{t}_{\mathrm{n}}\right)$

- Hewan uji diinduksi hiperglikemia dengan pemberian aloksan $200 \mathrm{mg} / \mathrm{kg}$ BB tikus putih secara intraperitonial. ${ }^{5}$

- Setelah 2 hari induksi, kadar gula darah diukur dari tikus putih jantan pada masing-masing kelompok, yang diambil lewat sinus marginalis sebelum induksi $\left(\mathrm{t}_{0}\right)$

- Dilakukan pemberian perlakuan selama 6 hari sesuai masing-masing kelompok 
sebagai berikut :

Kelompok I: kelompok perlakuan dengan Aquadest dosis 2,5 ml/200 g BB

b. Kelompok II: kelompok perlakuan dengan Insulin Novomix 0,9 $\mathrm{iu} / 200 \mathrm{~g} \mathrm{BB}$

c. Kelompok III: kelompok perlakuan dengan ekstrak daun Gedi Merah dosis 1,25 mg/200 g BB

d. Kelompok IV: kelompok perlakuan dengan ekstrak daun Gedi Merah dosis 2,5 mg/200 g BB

Kelompok V: kelompok perlakuan dengan ekstrak daun Gedi Merah dosis $3,75 \mathrm{mg} / 200 \mathrm{~g} \mathrm{BB}$

- Hewan uji dipuasakan sebelum diukur kadar gula darah. Selama puasa hewan uji tidak makan tetapi tetap diberi minum cukup. ${ }^{6}$

- Kadar gula darah tikus putih diukur kembali pada masing-masing kelompok, yang diambil lewat sinus marginalis sesudah pemberian perlakuan pada jam ke- $0\left(\mathrm{t}_{0}\right)$, ke-6 $\left(\mathrm{t}_{6}\right)$, ke-12 $\left(\mathrm{t}_{12}\right)$, ke-18 $\left(\mathrm{t}_{18}\right)$, dan ke-24 ( $\left.\mathrm{t}_{24}\right)$.

- Hewan uji dibiarkan washed out selama 48 jam.

- Hewan uji diberi perlakuan kedua sesuai masing-masing kelompok, kemudian dilakukan pengukuran kadar glukosa darah pada jam ke-0 $\left(\mathrm{t}_{0}\right)$, ke-6 $\left(\mathrm{t}_{6}\right)$, ke-12 $\left(\mathrm{t}_{12}\right)$, ke-18 $\left(\mathrm{t}_{18}\right)$, dan ke-24 ( $\left.\mathrm{t}_{24}\right)$.

- Hewan uji dibiarkan washed out selama 48 jam.

- Hewan uji diberi perlakuan ketiga sesuai masing-masing kelompok, kemudian dilakukan pengukuran kadar glukosa darah pada jam ke-0 $\left(\mathrm{t}_{0}\right)$, ke-6 $\left(\mathrm{t}_{6}\right)$, ke-12 $\left(\mathrm{t}_{12}\right)$, ke-18 $\left(\mathrm{t}_{18}\right)$, dan ke-24 $\left(\mathrm{t}_{24}\right)$.

\section{Pengukuran Kadar Glukosa Darah}

Kadar gula darah tikus putih diukur kembali pada masing-masing kelompok, yang diambil lewat sinus marginalis sesudah pemberian perlakuan pada jam ke$0\left(\mathrm{t}_{0}\right)$, ke-6 $\left(\mathrm{t}_{6}\right)$, ke-12 $\left(\mathrm{t}_{12}\right)$, ke-18 $\left(\mathrm{t}_{18}\right)$, dan ke-24 $\left(\mathrm{t}_{24}\right)$.

Nilai-nilai kadar gula darah yang diperoleh dari pengukuran pada 5 kelompok yang berbeda disajikan dalam tabel, dan dihitung reratanya serta dibuat dalam gambar kurva.

\section{HASIL PENELITIAN}

Rerata kadar glukosa darah kelompok kontrol negatif Aquadest dengan dosis 2,5 $\mathrm{ml} / 200$ g BB sebelum perlakuan (jam ke-0) $597 \mathrm{mg} / \mathrm{dl}$, menjadi 595,44 mg/dl pada jam ke-6, selanjutnya pada jam ke-12 menjadi 599,67 mg/dl, pada jam ke-18 menjadi 596,67 dan pada jam ke-24 menjadi 597 $\mathrm{mg} / \mathrm{dl}$.

Rerata kadar glukosa darah kelompok kontrol positif Insulin Novomix dengan dosis $0,9 \mathrm{iu} / 200 \mathrm{~g}$ BB dari $575,33 \mathrm{mg} / \mathrm{dl}$ sebelum perlakuan (jam ke-0) menjadi 206,22 mg/dl pada jam ke-6, pada jam ke12 menjadi 131,67 mg/dl, pada jam ke-18 menjadi $67,89 \mathrm{mg} / \mathrm{dl}$, dan pada jam ke-24 menjadi 337,22 mg/dl.

Pada kelompok perlakuan ekstrak Gedi Merah 1,25 mg/200 g BB tikus putih rerata kadar glukosa darah dari 594,33 $\mathrm{mg} / \mathrm{dl}$ sebelum perlakuan (jam ke-0) menjadi 589,89 mg/dl pada jam ke-6, selanjutnya pada jam ke-12 menjadi 595,44 mg/dl, kadar glukosa darah pada jam ke-18 mengalami penurunan menjadi 559, 55 mg/dl dan pada jam ke-24 menjadi 541,89 $\mathrm{mg} / \mathrm{dl}$.

Pada kelompok perlakuan ekstrak Gedi Merah dengan dosis 2,5 mg/200 g BB tikus putih rerata kadar glukosa darah mengalami peningkatan dari 582,56 mg/dl sebelum perlakuan (jam ke-0) menjadi 595,89 mg/dl pada jam ke-6, pada jam ke12 mengalami penurunan menjadi 593,56 mg/dl, pada jam ke-18 menjadi 558,22 $\mathrm{mg} / \mathrm{dl}$ dan pada jam ke-24 menjadi 532,22 $\mathrm{mg} / \mathrm{dl}$.

Pada kelompok perlakuan ekstrak Gedi Merah 3,75 mg/200 g BB tikus putih rerata kadar glukosa darah mengalami peningkatan dari 576,33mg/dl sebelum perlakuan (jam ke-0) menjadi 594,22 mg/dl pada jam ke-6, pada jam ke-12 mengalami penurunan menjadi $572,44 \mathrm{mg} / \mathrm{dl}$, pada jam ke-18 menjadi $534 \mathrm{mg} / \mathrm{dl}$ dan pada jam ke24 menjadi 471,55 mg/dl. 
Secara umum dapat dilihat bahwa rerata kadar glukosa darah meningkat setelah pemberian aloksan. Hal ini memberi gambaran bahwa pemberian aloksan dapat meningkatkan kadar glukosa darah tikus putih. Hasil pengukuran seluruh kelompok dapat dilihat pada Tabel 1.

Tabel 1. Kadar gula darah kelompok perlakuan

\begin{tabular}{cccccccc}
\hline Perlakuan & Tikus & \multicolumn{5}{c}{ Kadar Glukosa Darah $(\mathrm{mg} / 100 \mathrm{ml})$ pada jam ke : } \\
& No. & awal & 0 & 6 & 12 & 18 & 24 \\
\hline \multirow{3}{*}{ Kontrol Negatif } & 1 & 93 & 591 & 600 & 599 & 593,33 & 600 \\
& 2 & 84 & 600 & 597 & 600 & 600 & 591 \\
& 3 & 79 & 600 & 589,33 & 600 & 596,67 & 600 \\
\hline & 1 & 68 & 547,67 & 216,33 & 149,67 & 87,67 & 396,33 \\
Insulin & 2 & 81 & 588,67 & 183,67 & 109 & 56,67 & 291,67 \\
& 3 & 68 & 589,67 & 218,67 & 136,33 & 59,33 & 323,67 \\
\hline Ekstrak daun & 1 & 81 & 590,67 & 593 & 596 & 555,67 & 517 \\
Gedi Merah & 2 & 68 & 595,33 & 589,67 & 596,67 & 554,67 & 561,33 \\
1,25 mg/200 g BB & 3 & 93 & 597 & 587 & 593,67 & 568,33 & 547,33 \\
\hline Ekstrak daun & 1 & 87 & 553,33 & 591,67 & 595,33 & 570,67 & 541,67 \\
Gedi Merah & 2 & 83 & 598,33 & 596 & 596,67 & 542 & 520,33 \\
2,5 mg/200 g BB & 3 & 100 & 596 & 600 & 588,67 & 562 & 534,67 \\
\hline Ekstrak daun & 1 & 70 & 548 & 590,33 & 582,67 & 493 & 423 \\
Gedi Merah & 2 & 86 & 584 & 593 & 585,67 & 558,33 & 490,67 \\
3,75 mg/200 g BB & 3 & 84 & 583,67 & 599,33 & 549 & 550,67 & 501
\end{tabular}

Pola kurva pada kelompok kontrol negatif Aquadest dengan dosis 2,5 ml/ $200 \mathrm{~g} \mathrm{BB}$ tidak terjadi penurunan kadar glukosa darah. Pada kelompok kontrol positif Insulin Novomix dengan dosis $0,9 \mathrm{iu} / 200 \mathrm{~g}$ BB mengalami penurunan kadar glukosa darah pada jam ke-6, 12, dan 18, namun terjadi peningkatan pada jam ke-24. Pola kurva kelompok ekstrak Gedi Merah 1,25 mg/200 g BB terjadi penurunan kadar glukosa darah pada jam ke-18, sedangkan pola kurva kelompok ekstrak Gedi Merah dengan dosis 2,5 mg/200 g BB dan dosis $3,75 \mathrm{mg} / 200 \mathrm{~g}$ BB mempunyai gambaran yang sama yaitu terjadi penurunan kadar glukosa darah pada jam ke-12. Pola kurva seluruh kelompok dapat dilihat pada Gambar 1.

\section{BAHASAN}

Penelitian ini dilakukan untuk mengetahui efek ekstrak daun Gedi Merah dalam menurunkan kadar glukosa darah tikus diabetes yang diinduksi aloksan. Untuk membuat kondisi diabetes dalam penelitian ini menggunakan metode uji aloksan sebagai pemicu diabetes (diabetogen). Pemberian aloksan adalah cara yang cepat untuk menghasilkan kondisi diabetik eksperimental (hiperglikemik) pada binatang percobaan.

Kenaikan kadar glukosa darah pada tikus dipengaruhi oleh pemberian aloksan yang merusak sel beta pankreas melalui pembentukan senyawa reaktif $\mathrm{H}_{2} \mathrm{O}_{2}$ yang dapat berubah menjadi radikal hidroksil $\left(\mathrm{OH}^{0}\right)$. Selanjutnya $\mathrm{OH}^{0}$ menyebabkan fragmentasi DNA nukleus, kemudian terjadi aktivasi poli ADP-ribosa sintase, deplesi adenine dinukleotida (NAD) ${ }^{+}$ intrasel dan menyebabkan kerusakan pada sel beta pankreas. Peningkatan kadar gula darah pada tikus yang diinduksi dengan aloksan memiliki karakteristik seperti Diabetes Melitus tipe 1 pada manusia., ${ }^{7,8}$

Pada kelompok perlakuan tikus yang diberi analog insulin novomix kadar glukosa darah menurun, hal ini dikarenakan novomix merupakan analog insulin manusia yang dapat menurunkan kadar gula darah pada hewan uji. Novomix 
berikatan dengan reseptor-reseptor insulin untuk meningkatkan ambilan glukosa darah dan menghambat produksi glukosa hepar

sehingga dapat menurunkan kadar gula darah. $^{9}$

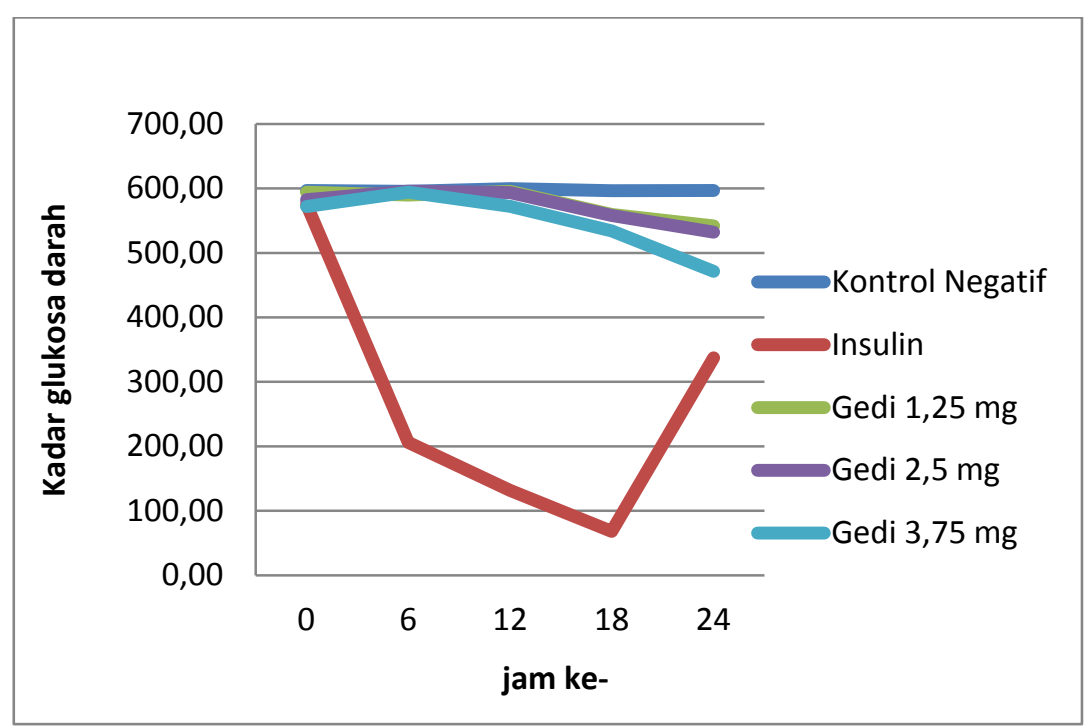

Gambar 1. Kurva kadar glukoda darah tikus putih setelah perlakuan dengan kontrol negatif Aquadest 2,5 ml/ $200 \mathrm{~g}$ BB, kontrol positif Insulin Novomix 0,9 iu/200 g BB, ekstrak Gedi Merah 1,25 mg/200 g BB, ekstrak Gedi Merah 2,5 mg/200 g BB dan ekstrak Gedi Merah 3,75 mg/200 g BB.

Efek penurunan kadar glukosa darah yang ditimbulkan oleh ekstrak daun Gedi Merah kemungkinan disebabkan oleh zat yang terkandung dalam Gedi Merah dapat merevitalisasi sel beta yang mengalami kerusakan. Hewan uji diberikan tiga kali perlakuan dengan washed out 48 jam. Tujuan dari washed out 48 jam diasumsikan obat telah bersih dalam darah. Untuk mengetahui kandungan zat aktif pada ekstrak daun Gedi Merah yang berperan pada penurunan kadar glukosa darah dan mekanisme aksi zat aktif yang dapat menurunkan kadar glukosa darah tikus diabetes karena pemberian aloksan diperlukan penelitian lebih lanjut.

\section{SIMPULAN DAN SARAN}

Dari hasil penelitian ini dapat disimpulkan bahwa ekstrak daun Gedi Merah dapat menurunkan kadar glukosa darah tikus yang diinduksi dengan aloksan.

Berdasarkan hasil penelitian perlu, disarankan untuk melakukan penelitian lebih lanjut dengan memperhatikan dosis dan lama perlakuan dengan metode penelitian yang lebih baik, serta gambaran histopatologi tikus putih yang diinduksi aloksan setelah pemberian ekstrak daun Gedi Merah.

\section{DAFTAR PUSTAKA}

1. Carolus F, Fatimawali, Wewengkang D. Uji Efektivitas Ekstrak Kulit Batang Jambu Mete (Anacardium Occidentale L.) terhadap Penurunan Kadar Glukosa Darah pada Tikus Putih Jantan Galur Wistar (Rattus norvegicus) yang Diinduksi Aloksan. Jurnal Ilmiah Farmasi Unsrat. Agustus 2014; 3(3):204-9. Available from:

http://ejournal.unsrat.ac.id/index.php/ pharmacon/article/viewFile/5371/487 9. Cited 2014 Sept 27.

2. Shahab A. Diagnosis dan Penatalaksanaan Diabetes Melitus. Konsensus Pengelolaan Diabetes Melitus di Indonesia. PERKENI 2006 [internet]. AVAilable from: http://dokteralwi.com/diabetes.html. Cited 2014 Sep 27. 
2. Assagaf F, Wullur A, Yudhistira A. Uji Toksisitas Akut Ekstrak Etanol Daun Gedi Merah (AbelmoschusmanihotL. Medik) terhadap Tikus Putih Jantan Galur Wistar (RattusnorvegicusL.). Pharmacon Jurnal Ilmiah Farmas iUnsrat. Februari 2013;2(1): p. 23-7.

3. Suoth E, Kaempe H, Tampi A. Evaluasi Kandungan Total Polifenol danIsolasi Senyawa Flavonoid pada Daun Gedi Merah (AbelmoschusmanihotL.). Chemistry Progress, Majalah Publikasi Ilmu Kimia. November 2013;6(2):86-9

4. Miya TS, Holck HG, Yim GK, et al. Laboratory Guide In Pharmacology. Burgess Publishing Company. 1973. p.44-6

5. Ngatidjan. Petunjuk Laboratorium, Metode Laboratorium dalam Toksikologi. Yogyakarta: Universitas Gadja Mada.1990. p. 24-52
6. Nugroho AE. Review: Hewan Percobaan Diabetes Melitus: Patologi dan Mekanisme Aksi Diabetogenik. Biodiversitas 2006;7(4);378-82. Available from: http://biodiversitas.mipa.uns.ac.id/D/ D070415.pdf. Cited 2015 Janl 19.

7. Watkins D, Coorperstein SJ, Lazarow A. Effect of Alloxan on permeability of pancreatic islet tissue in vitro. Availoable from:

http://ajplegacy.physiology.org/cgi/co ntent/abstract/207/2/436. Cited 2015 Jan 19.

8. Product information insulin aspart. Available from:

http://novonodisk.com.au/media/Pls/ Novorapid_NovoMix_P13a.pdf. Cited 2015 Jan 19. 